\title{
Mass development of phytoplankton in the River Warta in Poznań (Poland) in the $21^{\text {st }}$ century
}

\author{
Beata Mądrecka ${ }^{1}$, Elżbieta Szeląg-Wasielewska² \\ ${ }^{1}$ Poznań University of Technology, Faculty of Civil and Environmental Engineering, Institute of Environmental Engineering, Berdychowo 4, \\ 60-965 Poznań, Poland, e-mail: beata.madrecka@put.poznan.pl (corresponding author) \\ ${ }^{2}$ Adam Mickiewicz University in Poznań, Faculty of Biology, Department of Water Protection, Umultowska 89, 61-614 Poznań, Poland, \\ e-mail: eszelag@amu.edu.pl
}

\begin{abstract}
The first studies of phytoplankton of the River Warta in Poznań (Poland) were carried out in the 20 $0^{\text {th }}$ century (in 1922-23 and 1950-57). In the growing seasons the dominant groups were diatoms and green algae. Cyanobacteria were noted, but they did not have high abundance. The aim of this work is to present the phytoplankton research conducted on the River Warta in Poznań in the $21^{\text {st }}$ century (in 2003, 2009, 2010 and 2016). In all years the dominance of diatoms and green algae in terms of biomass was noted. However, in late summer cyanobacteria biomass was high and this group became dominant or co-dominant. Spring blooms were created by unicellular centric diatoms, e.g. Stephanodiscus minutulus and colonial green algae: Coelastrum microporum or Micractinium pusillum. In summer, bloom-forming taxa were unicellular centric diatoms, colonial diatoms: Aulacoseira granulata or Fragilaria crotonensis and cyanobacteria: Aphanizomenon flos-aquae and Woronichinia naegeliana. The occurrence of taxa typical of dam reservoirs and lakes suggests the influence of the Jeziorsko Reservoir on the phytoplankton of the River Warta, but it does not exclude the impact of tributaries and oxbow lakes. The research conducted in the $20^{\text {th }}$ and $21^{\text {st }}$ century show important changes in the taxonomical structure and abundance of phytoplankton.
\end{abstract}

Key words: eutrophic river, water bloom, cyanobacteria, Aphanizomenon flos-aquae

\section{Introduction}

Intensive development of phytoplankton, including cyanobacteria, often occurs in different kinds of water bodies as a result of the water eutrophication and the global climate change of recent decades (O’Neil 2012). Cyanobacteria blooms have been observed in numerous lakes and reservoirs in Poland (Zagajewski et al. 2007; Grabowska and Mazur-Marzec 2011; Mankiewicz-Boczek et al. 2011; Kobos et al. 2013; Gągała et al. 2014) and many other countries around the world (Carmichael 2008; Merel et al. 2013). They have also been noted in eutrophic rivers, e.g. in the River Nakdong in South Korea (Ha et al. 1998) in the River Murrey in Australia (Al-Tebrineh et al. 2012) and in the River Nile in Egypt (Mohamed et al. 2015). In Poland they have been observed in e.g. the River Narew (Grabowska and Mazur-Marzec 2011) and in the River Obrzyca (Piontek et al. 2017).

Growth of phytoplankton in rivers is intensified by nutrients flowing from the catchment area, the presence of nutrient and phytoplankton rich tributaries
(Istvánovics et al. 2010), oxbow lakes (Grabowska et al. 2014), and dam reservoirs (Prygiel and Leitao 1994; Kasza 2009; Grabowska 2012; Mądrecka 2015).

Rivers are very unstable environments for phytoplankton development because of constant water flow and water turbulence. Another important factor affecting phytoplankton is light availability, which can be significantly limited by high water turbidity (Allan and Castillo 2009). Moreover, the environment of the riverbed is inhomogeneous. There are areas characterized by reduced water discharge and increased concentration of different nutrients, in which phytoplankton can develop more intensively, called "dead-zones" or "storagezones". These areas also include backwaters and river branches (Reynolds and Descy 1996; Reynolds 2000).

Instability and heterogeneity of river water lead to frequent structural changes in taxonomy and phytoplankton concentration. This shows the importance of continuous and long-lasting monitoring research which can extend our knowledge of the ecology of bloom-forming taxa in rivers. It is also necessary and helpful from the point of view of water quality assess- 
ment and limitation of harmful effects of water bloom e.g. high concentration of cyanotoxins in river water.

The aim of this work is to present a taxonomical and quantitative analysis of phytoplankton of the River Warta in Poznan at the beginning of the $21^{\text {st }}$ century against the background of previous research. Particular attention is focused on dominant phytoplankton groups and bloom-forming taxa.

\section{Methods}

Water samples for physical, chemical, chlorophyll- $a$ and phytoplankton analyses were taken from the current of the River Warta in the city center of Poznan near Queen Jadwiga Bridge in 2003 or near Saint Roch Bridge in 2009, 2010 and 2016 (244.5 km of river flow) (Fig. 1). In 2003 a monitoring study was conducted and the samples were collected only between the end of May to October - once a month (in May and October) or twice a month (from June to September). In this year total phytoplankton biomass and chemical parameters were not analyzed. In 2009, 2010 and 2016 the frequency of sampling was once a month (in March and April) or twice a month (from May to October).

Water samples for phytoplankton studies were collected in polyethylene bottles and preserved with Lugol's solution. Samples for autotrophic picoplankton (APP) study were conserved with buffered glutaraldehyde to obtain the final concentration of 1-2\% (Hawley

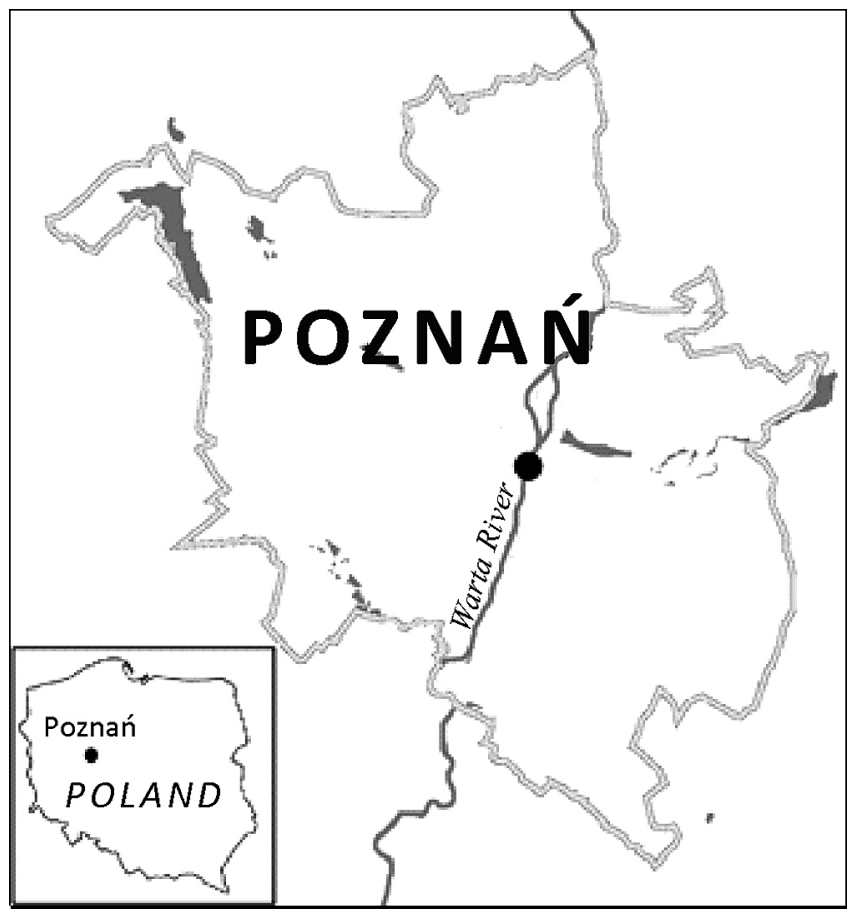

Fig. 1. Locality of the city of Poznan and the sampling site (black circle) and Whitton 1991a). Water temperature and $\mathrm{pH}$ were measured directly at the sampling site.

Phytoplankton taxonomy and the amount of cells was studied with a light microscope (Olympus BX-60) and an inverted microscope (MOD-2, Motic AE31) after sedimentation in settling chambers according to the method by Utermöhl (Wetzel and Likens 1991). Autotrophic picoplankton subsamples (of $1 \mathrm{~cm}^{3}$ volume) were filtered through nucleopore black filters with a diameter of $25 \mathrm{~mm}$ and a pore size of $0.2 \mu \mathrm{m}$ at low vacuum pressure. Then, APP cells were dyed with the use of fluorochrome DAPI (4',6-diamidino-2-fenylindol) (Porter and Feig 1980) and analyzed using an epifluorescence microscope (Olympus BX-60). Biovolume of phytoplankton taxa was calculated on the basis of cell volume and their abundance. Biomass was expressed as wet weight, assuming that the volume of $10^{6} \mu \mathrm{m}^{3}$ is equivalent to $1 \mu \mathrm{g}$ (wet weight) (Amblard et al. 1995). The threshold value of water bloom was $10 \mathrm{mg} \mathrm{dm}^{-3}$ of phytoplankton biomass according to the criterion of Pavoni (1963).

Chlorophyll-a concentrations were determined spectrophotometrically after filtration through Whatman GF/F glass fiber filters and extraction in $90 \%$ acetone. Standard methods were used for analyses of concentrations of phosphates, mineral forms of nitrogen, total phosphorus and total nitrogen (Hermanowicz et al. 1999).

Hydrological data - water level and water discharge of the River Warta near Saint Roch Bridge were obtained from the database of the Institute of Meteorology and Water Management available on the website (https://dane.imgw.pl).

\section{Study area}

The River Warta is the third longest river in Poland $(808.2 \mathrm{~km})$. The sampling station was located in the center of the city of Poznan in the Greater Poland Voivodeship. In this area the Warta flows in a northerly direction within the geographical mesoregion known as the Poznan Ravine of the Warta River, which is part of the Greater Poland Lakeland. Through almost all the area of the Greater Poland Voivodeship it is classified as abiotic type 21 (large lowland rivers). According to data of the Central Statistical Office of Poland (GUS 2016) mean annual discharge calculated for the years 1951-2010 at the stream gauge near Saint Roch Bridge is $102 \mathrm{~m}^{3} \mathrm{~s}^{-1}$.

The River Warta is highly eutrophic and is subject to strong anthropogenic influence. The catchment area of the Greater Poland Voivodeship is $26.7 \times 10^{3} \mathrm{~km}$. About $65 \%$ of it is used as farmland - mainly arable land. The Warta also has many tributaries rich in nutrients and 
is a receiver of wastewater from many municipal and industrial wastewater plants. At $484.3 \mathrm{~km}$ of river flow there is also the dam of the Jeziorsko Reservoir whose max. volume is $202.8 \times 10^{6} \mathrm{~m}^{3}$ and max. area is $42.3 \mathrm{~km}^{2}$. This reservoir has been operating since 1986, but its first maximal impoundment was achieved in 1992 (RZGW 2007).

The River Warta is used for industry - particularly for the energy industry, for agricultural irrigation and fishery management. It is also the source of drinking water for the inhabitants of Poznań (Pułyk 2010). In Poznań the river and its adjacent area are increasingly used for recreational purposes.

\section{Results}

In the studied years values of the water level were similar and were in the range of low or middle water level zone (Table 1). The exception was the level noted in 2010, whose values were in the middle or high water level zone. In this year in May and June the values exceeded the warning state and were higher than 400 $\mathrm{cm}$, as a result of flood wave propagation. The ranges and mean values of water discharge were also similar in 2003, 2009 and 2016. They did not usually exceed diurnal mean annual water discharge calculated for this river. Higher values were observed only in March and April of 2009 and 2016 during the melt. In the case of 2010 , the mean value of water discharge was approximately 3 -fold higher than in the other years. Mean values of water temperature were similar in 2009, 2010 and 2016 and amounted to $16.0-16.5^{\circ} \mathrm{C}$. The mean value in 2003 was higher because of the smaller number of samples. The $\mathrm{pH}$ value was usually slightly alkaline (8.208.89).

Table 1. Hydrological, physical, chemical and biological parameters of water during the growing season (March-October) in 4 investigated years (mean values were put in brackets)

\begin{tabular}{lccccc}
\hline \multicolumn{1}{c}{ Parameter } & Unit & $2003^{*}$ & 2009 & 2010 & 2016 \\
\hline Water level & {$[\mathrm{cm}]$} & $141-244(171)$ & $160-270(200)$ & $219-484(320)$ & $137.5-267.5(176.5)$ \\
\hline Water discharge & {$\left[\mathrm{m}^{3} \mathrm{~s}^{-1}\right]$} & $38.5-88.0(52.1)$ & $46.1-113.0(69.6)$ & $80.4-302.0(156)$ & $34.0-109.0(55.4)$ \\
\hline Water temperature & {$\left[{ }^{\circ} \mathrm{C}\right]$} & $6.8-25.5(19.5)$ & $4.2-23.7(16.2)$ & $7.3-26.0(16.0)$ & $5.5-22.9(16.5)$ \\
\hline $\mathrm{pH}$ & & $7.78-9.52(8.89)$ & $7.94-9.11(8.33)$ & $7.55-8.60(8.20)$ & $8.00-8.80(8.36)$ \\
\hline Mineral nitrogen & {$\left[\mathrm{mg} \mathrm{N} \mathrm{dm}^{-3}\right]$} & $\mathrm{NA}$ & $0.725-2.545^{*}(1.363)^{*}$ & $1.387-3.036(2.103)$ & $0.147-0.958(0.620)$ \\
\hline Total nitrogen & {$\left[\mathrm{mg} \mathrm{N} \mathrm{dm}^{-3}\right]$} & $\mathrm{NA}$ & $2.754-4.399^{*}(3.870)^{*}$ & $3.536-6.521(4.296)$ & $1.774-3.149(2.551)$ \\
\hline Phosphates & {$\left[\mathrm{mg} \mathrm{P} \mathrm{dm}^{-3}\right]$} & $\mathrm{NA}$ & $0.051-0.179^{*}(0.124)^{*}$ & $0.048-0.203(0.114)$ & $0.076-0.206(0.140)$ \\
\hline Total phosphorus & {$\left[\mathrm{mg} \mathrm{P} \mathrm{dm}^{-3}\right]$} & $\mathrm{NA}$ & $0.071-0.850^{*}(0.240)^{*}$ & $0.116-0.750(0.243)$ & $0.202-0.368(0.273)$ \\
\hline Chlorophyll-a & {$\left[\mathrm{fg} \mathrm{dm}^{-3}\right]$} & $2.5-155.3(78.0)$ & $5.6-133.0(44.3)$ & $1.6-75.4(26.5)$ & $19.6-150.8(82.0)$ \\
\hline Total phytoplankton abundance & {$\left[10^{3} \mathrm{cells} \mathrm{cm}^{-3}\right]$} & $\mathrm{NA}$ & $5.5-267.4(76.0)$ & $4.4-203.4(62.8)$ & \\
\hline $\begin{array}{l}\text { Phytoplankton abundance } \\
\text { without APP }\end{array}$ & {$\left[10^{3} \mathrm{cells} \mathrm{cm}^{-3}\right]$} & $\mathrm{NA}$ & $4.3-263.1(58.5)$ & $1.5-170.2(39.3)$ & $14.3-374.9(139.9)$ \\
\hline APP abundance & {$\left[10^{3} \mathrm{cells} \mathrm{cm}^{-3}\right]$} & $1.3-105.0(35.4)$ & $1.2-55.6(17.5)$ & $0.8-81.2(23.5)$ &
\end{tabular}

* - analyzed since May to October only; NA - not analyzed.
Concentration of total nitrogen and total phosphorus was high and indicative of the high trophic state of the river. In 2016 the mean value of mineral forms of nitrogen was approx. 2-3 times lower than in 2009 and 2010 (Table 1). Mean values of phosphates were similar in the 3 investigated years and amounted to 0.114$0.140 \mathrm{mg} \mathrm{P} \mathrm{dm}^{-3}$. In 2003, 2009 and 2016 concentration of chlorophyll- $a$ exceeded $30 \mu \mathrm{g} \mathrm{dm}{ }^{-3}$ in the majority of samples, which confirmed the high trophy of the Warta according to the criterion proposed by Dodds et al. (1998). Lower values of this parameter were noted in 2010 (only in 3 samples was concentration $>30 \mu \mathrm{g} \mathrm{dm}-$ $\left.{ }^{3}\right)$.

The total amount of phytoplankton was variable in each growing season, but usually exceeded $10^{4}$ cells per cubic centimeter. The mean value of autotrophic picoplankton ranged from 17.5 to $35.4 \times 10^{3}$ cells $\mathrm{cm}^{-3}$ (Table 1). The most important taxa from this size group were cyanobacteria: Synechocystis, Synechococcus, Aphanocapsa, Cyanogranis ferruginea, Mersmopedia tenuissima and green algae: Chlorella, Choricystis, Pseudodictyosphaerium jurisii.

The high value of phytoplankton biomass exceeding $10 \mathrm{mg} \mathrm{dm}^{-3}$ indicated the occurrence of spring and summer water blooms in the River Warta (Fig. 2). In the spring of 2003 the water bloom was caused by unicellular centric diatoms and colonial green algae, whereas in 2016 it was mainly caused by the unicellular centric diatoms. In all the studied years, at the beginning of summer, the water blooms were formed by unicellular centric diatoms (in 2003, 2009, 2016) and/ or colonial diatoms (in 2009, 2016), but in the late summer water blooms were formed by cyanobacteria (in $2009,2003,2016$ ), diatoms (in 2003, 2010) and green algae (in 2016) (Tables 2 and 3). Taxonomical groups of phytoplankton noted in the Warta in low biomass were: 


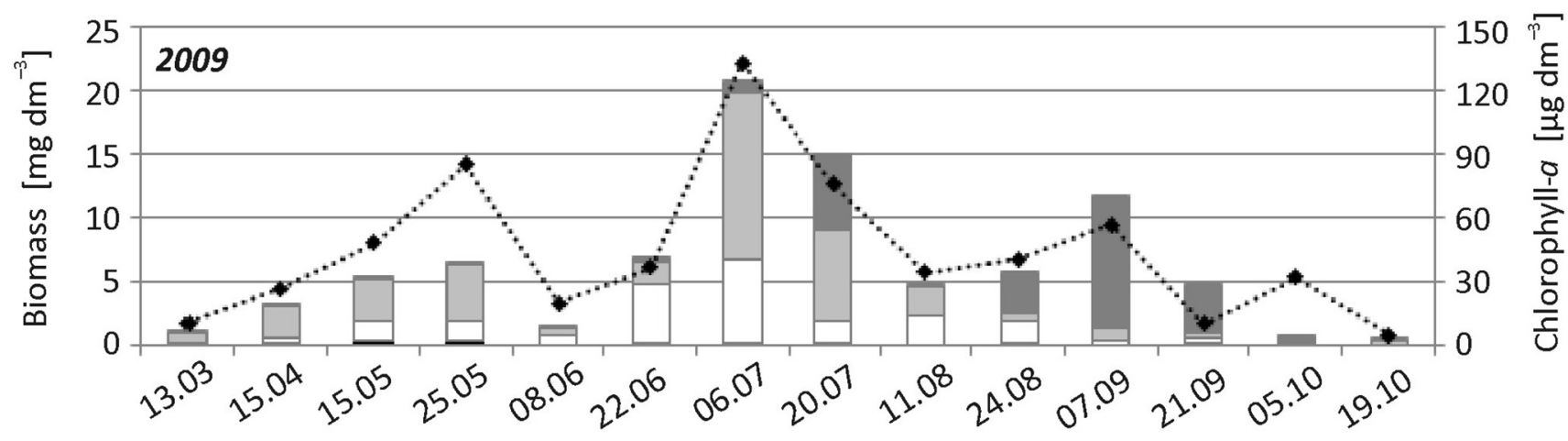

Date of sampling

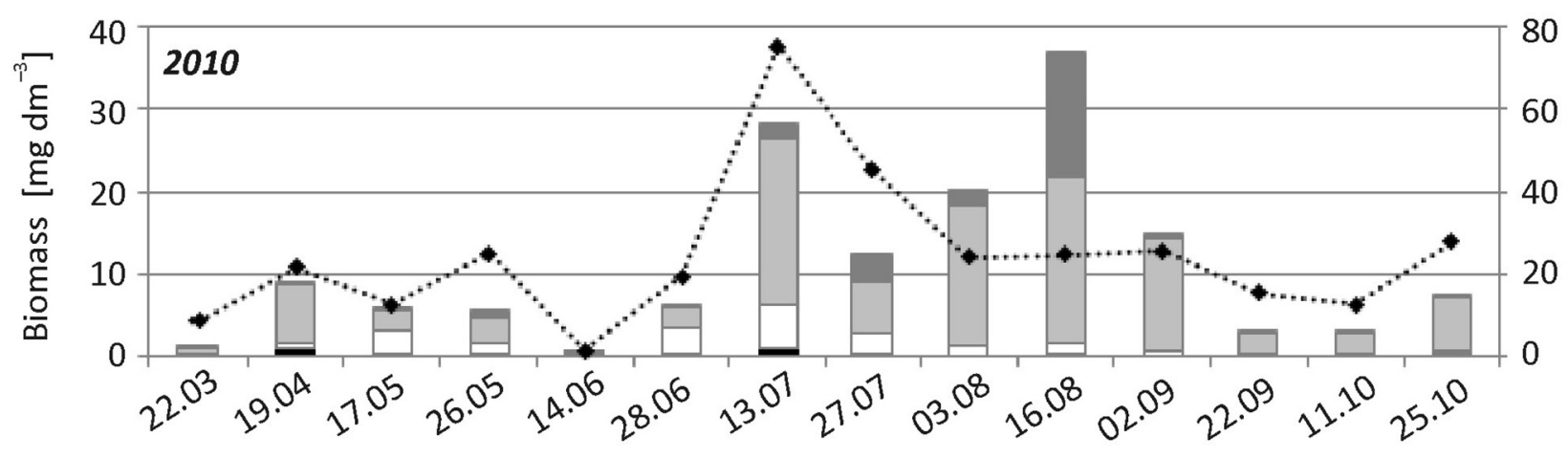

Date of sampling

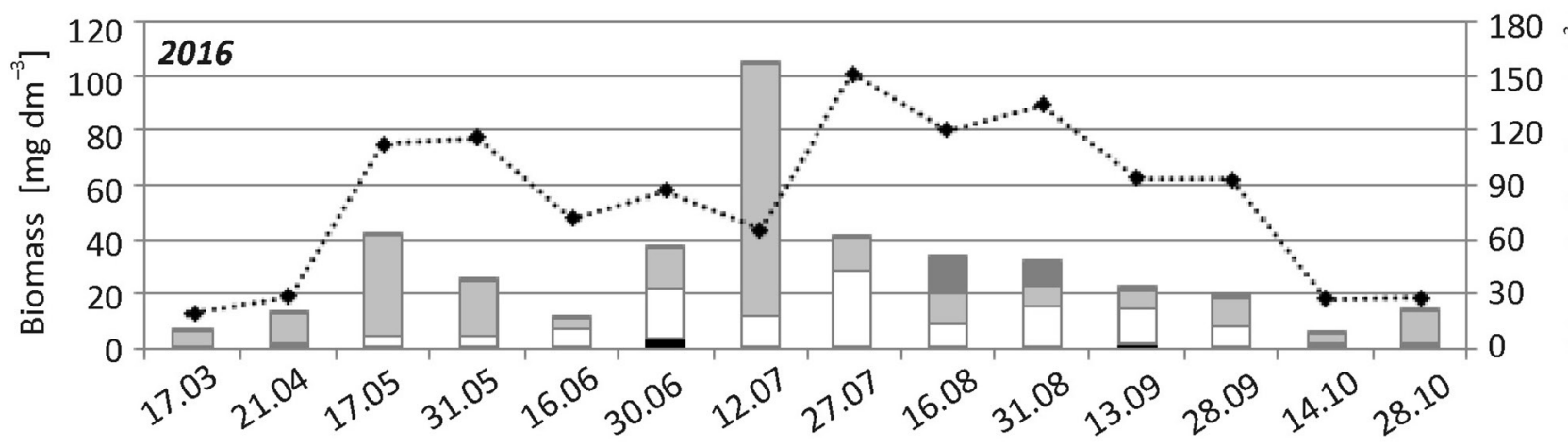

Date of sampling

Fig. 2. Biomass of dominant phytoplankton groups and concentration of chlorophyll- $a$ in the River Warta in 2009,2010 and 2016

Chrysophyceae, Cryptophyceae, Euglenophyta, Dinophyta, Xanthophyceae.

Unicellular centric diatoms with the highest biomass were taxa of the genera: Stephanodiscus, Cyclostephanos, Cyclotella, Thalassiosira, Actinocyclus. Their mass occurrence was observed in May of 2003 and 2016, when their biomass exceeded $40 \mathrm{mg} \mathrm{dm}^{-3}$ (Table 2). In 2016 the water bloom was the effect of the intensive growth of Stephanodiscus minutulus. Colonial diatoms in turn form water blooms in the summer - Aulacosei- ra granulata in 2009 and Fragilaria crotonensis in 2010 and 2016. In July of 2016 F. crotonensis had the highest biomass - over $75 \mathrm{mg} \mathrm{dm}^{-3}$ (Table 3 ).

As regards green algae, in June of 2003, the taxon with the highest biomass was Coelastrum microporum $\left(10.3 \mathrm{mg} \mathrm{dm}^{-3}\right)$ (Table 2). Other taxa with high biomass were: Micractinium pusillum (in 2016), Pediastrum (in 2016) and Scenedesmus/Desmodesmus (in all investigated years). High cell abundance but small biomass was observed in the case of taxa characterized by small cell 
Table 2. Taxa with the highest biomass ( $>10 \%$ of total phytoplankton biomass - TPB) noted in 2003 and 2009

\begin{tabular}{|c|c|c|c|}
\hline Date & Taxa & $\begin{array}{c}\text { Biomass } \\
{\left[\mathrm{mg} \mathrm{dm}^{-3}\right]}\end{array}$ & $\%$ of TPB \\
\hline \multicolumn{4}{|c|}{2003} \\
\hline 25 May & unicellular centric diatoms* & 66.33 & NA \\
\hline \multirow[t]{2}{*}{6 June } & unicellular centric diatoms* & 16.80 & NA \\
\hline & Coelastrum microporum & 8.69 & NA \\
\hline \multirow[t]{2}{*}{25 June } & unicellular centric diatoms* & 15.30 & NA \\
\hline & Coelastrum microporum & 10.33 & NA \\
\hline 5 July & unicellular centric diatoms ${ }^{*}$ & 4.51 & NA \\
\hline 23 July & unicellular centric diatoms ${ }^{*}$ & 21.90 & NA \\
\hline 7 Aug. & unicellular centric diatoms ${ }^{*}$ & 14.25 & NA \\
\hline \multirow[t]{2}{*}{22 Aug. } & Aphanizomenon flos-aquae & 11.17 & NA \\
\hline & unicellular centric diatoms ${ }^{*}$ & 11.10 & NA \\
\hline 6 Sep. & unicellular centric diatoms ${ }^{*}$ & 5.10 & NA \\
\hline 26 Sep. & unicellular centric diatoms ${ }^{*}$ & 2.85 & NA \\
\hline 22 Oct. & unicellular centric diatoms ${ }^{*}$ & 0.63 & NA \\
\hline \multicolumn{4}{|c|}{2009} \\
\hline \multirow[t]{2}{*}{13 Mar. } & unicellular centric diatoms* & 0.46 & 45.9 \\
\hline & Gyrosigma acuminatum & 0.13 & 13.2 \\
\hline 15 Apr. & unicellular centric diatoms ${ }^{*}$ & 1.86 & 57.0 \\
\hline \multirow[t]{2}{*}{15 May } & unicellular centric diatoms* & 1.32 & 25.5 \\
\hline & Nitzschia acicularis & 1.24 & 23.9 \\
\hline \multirow[t]{3}{*}{25 May } & Fragilaria crotonensis & 1.47 & 22.9 \\
\hline & unicellular centric diatoms* & 1.17 & 18.3 \\
\hline & Nitzschia acicularis & 0.85 & 13.2 \\
\hline 8 June & unicellular centric diatoms* & 0.45 & 30.6 \\
\hline 22 June & unicellular centric diatoms ${ }^{*}$ & 1.15 & 16.4 \\
\hline 6 July & unicellular centric diatoms* & 10.57 & 50.3 \\
\hline \multirow[t]{2}{*}{20 July } & Aphanizomenon flos-aquae & 5.47 & 36.4 \\
\hline & Aulacoseira granulata & 5.33 & 35.4 \\
\hline 11 Aug. & unicellular centric diatoms ${ }^{*}$ & 1.78 & 36.6 \\
\hline \multirow[t]{2}{*}{24 Aug. } & Microcystis flos-aquae & 1.64 & 28.0 \\
\hline & Aphanizomenon flos-aquae & 1.37 & 23.3 \\
\hline \multirow[t]{2}{*}{7 Sep. } & Aphanizomenon flos-aquae & 6.70 & 57.2 \\
\hline & Microcystis flos-aquae & 2.93 & 25.0 \\
\hline 21 Sep. & Microcystis aeruginosa & 3.61 & 74.6 \\
\hline \multirow[t]{2}{*}{5 Oct. } & Aphanizomenon flos-aquae & 0.25 & 27.1 \\
\hline & unicellular centric diatoms ${ }^{*}$ & 0.10 & 11.2 \\
\hline 19 Oct. & Pseudanabaena mucicola & 0.20 & 25.8 \\
\hline
\end{tabular}

Explanation: ${ }^{*}$ - small unicellular centric diatoms from genera: Stephanodiscus, Cyclostephanos, Cyclotella, Actinocyclus, Thalassiosira; NA - not analyzed.

size e.g. Actinastrum, Dictyosphaerium, Monoraphidium, Tetrastrum, Oocystis.

In each investigated year, in the second half of summer, the cyanobacteria developed more intensively (Fig. 2). At the end of August 2003, Aphanizomenon flos-aquae formed a water bloom in which it occurred in fascicle visible to the naked eye. Its biomass amounted to $11.17 \mathrm{mg} \mathrm{dm}^{-3}$ (water temperature was $22.0^{\circ} \mathrm{C}$ and $\mathrm{pH}=9.14$ ). A similar phenomenon took place on the $7^{\text {th }}$ September 2009, although its biomass was lower $\left(6.7 \mathrm{mg} \mathrm{dm}^{-3} ; 16.1^{\circ} \mathrm{C} ; \mathrm{pH}=8.3\right)$. On this date A. flos-
Table 3. Taxa with the highest biomass ( $>10 \%$ of total phytoplankton biomass - TPB) noted in 2010 and 2016

\begin{tabular}{|c|c|c|c|}
\hline Date & Taxa & $\begin{array}{l}\text { Biomass } \\
{\left[\mathrm{mg} \mathrm{dm}^{-3}\right]}\end{array}$ & $\%$ of TPB \\
\hline \multicolumn{4}{|c|}{2010} \\
\hline 22 Mar. & unicellular centric diatoms ${ }^{*}$ & 0.04 & 44.8 \\
\hline 19 Apr. & unicellular centric diatoms ${ }^{*}$ & 5.21 & 59.4 \\
\hline 17 May & $\begin{array}{l}\text { Ulotrichales } \\
\text { unicellular centric diatoms* }\end{array}$ & $\begin{array}{l}2.19 \\
2.00\end{array}$ & $\begin{array}{l}39.2 \\
35.9\end{array}$ \\
\hline 26 May & $\begin{array}{l}\text { unicellular centric diatoms }{ }^{*} \\
P s e u d a n a b a e n a ~ l i m n e t i c a\end{array}$ & $\begin{array}{l}2.25 \\
0.80\end{array}$ & $\begin{array}{l}40.7 \\
14.5\end{array}$ \\
\hline 14 June & $\begin{array}{l}\text { Closterium spp. } \\
\text { unicellular centric diatoms* }\end{array}$ & $\begin{array}{l}0.09 \\
0.07\end{array}$ & $\begin{array}{l}21.7 \\
17.9\end{array}$ \\
\hline 28 June & $\begin{array}{l}\text { Chlorella spp. } \\
\text { unicellular centric diatoms* }\end{array}$ & $\begin{array}{l}2.31 \\
2.23 \\
\end{array}$ & $\begin{array}{l}38.6 \\
37.3 \\
\end{array}$ \\
\hline 13 July & unicellular centric diatoms ${ }^{*}$ & 1.53 & 54.2 \\
\hline 27 July & $\begin{array}{l}\text { Fragilaria crotonensis } \\
\text { Microcystis aeruginosa }\end{array}$ & $\begin{array}{l}3.37 \\
2.49\end{array}$ & $\begin{array}{l}27.1 \\
20.1\end{array}$ \\
\hline 3 Aug. & Fragilaria crotonensis & 16.34 & 81.0 \\
\hline 16 Aug. & $\begin{array}{l}\text { Fragilaria crotonensis } \\
\text { Aphanizomenon flos-aquae }\end{array}$ & $\begin{array}{l}19.38 \\
14.51\end{array}$ & $\begin{array}{l}52.3 \\
39.2\end{array}$ \\
\hline 2 Sep. & Fragilaria crotonensis & 12.75 & 84.7 \\
\hline 22 Sep. & $\begin{array}{l}\text { unicellular centric diatoms* } \\
\text { Fragilaria crotonensis }\end{array}$ & $\begin{array}{l}1.06 \\
0.85\end{array}$ & $\begin{array}{l}35.9 \\
28.5\end{array}$ \\
\hline 11 Oct. & unicellular centric diatoms ${ }^{*}$ & 1.92 & 68.5 \\
\hline 25 Oct. & $\begin{array}{l}\text { unicellular centric diatoms* } \\
\text { Fragilaria crotonensis }\end{array}$ & $\begin{array}{l}4.77 \\
1.37\end{array}$ & $\begin{array}{l}66.8 \\
19.2\end{array}$ \\
\hline \multicolumn{4}{|c|}{2016} \\
\hline 17 Mar. & $\begin{array}{l}\text { unicellular centric diatoms* } \\
\text { Asterionella formosa }\end{array}$ & $\begin{array}{l}3.16 \\
1.89 \\
\end{array}$ & $\begin{array}{l}48.6 \\
29.0\end{array}$ \\
\hline 21 Apr. & $\begin{array}{l}\text { Asterionella formosa } \\
\text { unicellular centric diatoms }\end{array}$ & $\begin{array}{l}4.35 \\
2.63\end{array}$ & $\begin{array}{l}32.7 \\
19.8\end{array}$ \\
\hline 17 May & unicellular centric diatoms ${ }^{*}$ & 34.05 & 82.7 \\
\hline 31 May & unicellular centric diatoms* & 16.80 & 67.3 \\
\hline 16 June & $\begin{array}{l}\text { unicellular centric diatoms }{ }^{*} \\
\text { Pediastrum duplex }\end{array}$ & $\begin{array}{l}2.17 \\
1.28\end{array}$ & $\begin{array}{l}20.2 \\
11.9\end{array}$ \\
\hline 30 June & $\begin{array}{l}\text { unicellular centric diatoms* } \\
\text { Micractinium pusillum }\end{array}$ & $\begin{array}{l}9.84 \\
3.89\end{array}$ & $\begin{array}{l}26.6 \\
10.5\end{array}$ \\
\hline 12 July & $\begin{array}{l}\text { Fragilaria crotonensis } \\
\text { unicellular centric diatoms* }\end{array}$ & $\begin{array}{l}75.31 \\
14.21\end{array}$ & $\begin{array}{l}71.3 \\
13.5\end{array}$ \\
\hline 27July & $\begin{array}{l}\text { unicellular centric diatoms* } \\
\text { Pediastrum duplex }\end{array}$ & $\begin{array}{l}7.75 \\
5.12\end{array}$ & $\begin{array}{l}18.7 \\
12.3\end{array}$ \\
\hline 16 Aug. & $\begin{array}{l}\text { Woronichinia naegeliana } \\
\text { Fragilaria crotonensis } \\
\text { unicellular centric diatoms* }\end{array}$ & $\begin{array}{r}11.48 \\
5.41 \\
3.96 \\
\end{array}$ & $\begin{array}{l}34.0 \\
16.0 \\
11.7 \\
\end{array}$ \\
\hline 31 Aug. & $\begin{array}{l}\text { Woronichinia naegeliana } \\
\text { unicellular centric diatoms* } \\
\text { Micractinium pusillum }\end{array}$ & $\begin{array}{l}8.76 \\
4.83 \\
3.85 \\
\end{array}$ & $\begin{array}{l}26.9 \\
14.8 \\
11.8 \\
\end{array}$ \\
\hline 13 Sep. & $\begin{array}{l}\text { unicellular centric diatoms } \\
\text { Micractinium pusillum }\end{array}$ & $\begin{array}{l}4.52 \\
2.28\end{array}$ & $\begin{array}{l}20.0 \\
10.0\end{array}$ \\
\hline 28 Sep. & $\begin{array}{l}\text { unicellular centric diatoms* } \\
\text { Micractinium pusillum }\end{array}$ & $\begin{array}{l}4.40 \\
2.97\end{array}$ & $\begin{array}{l}21.5 \\
14.5\end{array}$ \\
\hline 14 Oct. & unicellular centric diatoms* & 1.48 & 23.7 \\
\hline 28 Oct. & $\begin{array}{l}\text { Fragilaria crotonensis } \\
\text { unicellular centric diatoms }\end{array}$ & $\begin{array}{l}5.48 \\
5.09\end{array}$ & $\begin{array}{l}39.2 \\
36.4\end{array}$ \\
\hline
\end{tabular}

Explanation: ${ }^{*}$ - small unicellular centric diatoms from genera: Stephanodiscus, Cyclostephanos, Cyclotella, Actinocyclus, Thalassiosira. 
aquae dominated with Microcystis flos-aquae and their biomass together exceeded $82 \%$ of total phytoplankton biomass. A bloom of A. flos-aquae occurred again in August 2010 and achieved the highest biomass of $14.5 \mathrm{mg} \mathrm{dm}^{-3}\left(23.8^{\circ} \mathrm{C} ; \mathrm{pH}=7.5\right)$. This species was also noted in summer 2016 but its biomass was low. In August 2016, a mass occurrence of another cyanobacteria was observed - Woronichinia naegeliana. Its maximum value of biomass amounted to $11.5 \mathrm{mg} \mathrm{dm}^{-3}\left(19.3^{\circ} \mathrm{C}\right.$; $\mathrm{pH}=8.5$ ).

Other cyanobacteria taxa with a high biomass which occurred in the investigated growing seasons were: $\mathrm{Mi}$ crocystis aeruginosa, Pseudanabaena limnetica, Planktothrix aghardii, P. mucicola, Phormidium granulatum, $M$. wesenbergii, Dolichospermum flos-aquae, Planktolyngbya limnetica, Aphaniozmenon gracile, D. spiroides. Some rare species of cyanobacteria were also noted, but their biomass was low. These were: Cuspidothrix issatschenkoi, Sphaerospermopsis aphanizomenoides, Anabaenopsis elenkinii, A. milleri.

\section{Discussion}

In the River Warta the abundance of phytoplankton (without APP) was quite high but not similar in all the studied years. The mean cell number was the lowest in 2010, which was the effect of the high water discharge due to flooding at the end of May and beginning of June. High water discharge and water level of the river during the flood period led to an increase in the concentration of suspended matter, decrease of water transparency and diminishing of light conditions. These environmental factors limit phytoplankton growth and proliferation (Mihaljević et al. 2010). Decrease of phytoplankton biomass during flood was also observed in the River Danube (Mihaljević et al. 2010) and in Croatian floodplain rivers (Stanković et al. 2012). In the smaller, but also lowland river Narew below the Siemianówka Reservoir Grabowska (2012) noted a cell amount several times higher - from 6 to $1026.4 \times 10^{6}$ cells $\mathrm{cm}^{-3}$. In the River Wisła between Wyszogród and Toruń, characterized by a higher discharge than the Warta, the mean abundance of the phytoplankton amounted to $7.4 \times 10^{6}$ ind. $\mathrm{dm}^{-3}$ (Kentzer et al. 2010). In another Polish river - in the lower section of the Oder, Sługocki et al. (2014) noted approx. $200 \times 10^{3}$ ind. $\mathrm{dm}^{-3}$. Phytoplankton abundance in the River Morava (in the Czech Republic) ranged from 6.4 to 124.6 cells $\times 10^{3} \mathrm{~cm}^{-3}$ (Hašler et al. 2007).

Abundance of autotrophic picoplankton (APP) in the Warta was not high. In the Cybina - the tributary of the Warta, at sampling stations within the city of Poznan the total amout of picophytoplankton was several times higher and amounted to $0.35-2.9 \times 10^{5} \mathrm{cells} \mathrm{cm}^{-3}$ (SzelągWasielewska et al. 2005). Strzeszyńskie Lake located in
Poznań was also characterized by higher abundance of APP and amounted to $0.1-8.1 \times 10^{5}$ cells $\mathrm{cm}^{-3}$ (SzelągWasielewska 2004). The participation of APP as a component of the total phytoplankton biomass in the Warta was not significant. This confirms the observation of Hawley and Whitton (1991b), that relative contribution of APP to total phytoplankton biomass is the lowest when the trophic state is high. Autotrophic picoplankton is observed in waters of different trophic state, but studies show the sensitivity of APP to eutrophication, and also to water contamination, especially with heavy metals (Severn et al. 1989; Weisse 1991; Weisse and Mindl 2002). The environment of the eutrophic and polluted River Warta does not favor APP development.

Analysis of phytoplankton groups revealed the dominance of diatoms, green algae and cyanobacteria in the growing seasons of the $21^{\text {st }}$ century, while studies conducted in the $20^{\text {th }}$ century indicated the significance of diatoms and green algae. The first comprehensive research of the phytoplankton of the River Warta near Poznań was conducted by Hoppówna (1925) in 19221923. The results of this study showed the dominance of diatoms and green algae in abundance. Cyanobacteria was rarely or occasionally found in phytoplankton. Studies carried out in 1950-52 (Kniat and Kołaczkowski 1963) and in 1953-60 (Kołaczkowski and Preis 1962) confirmed high diversity of diatoms and green algae in the growing season.

Both diatoms and green algae are specific phytoplankton groups for large, slow-flowing, lowland rivers. Unicellular centric diatoms (e.g. Stephanodiscus minutulus), Asterionella formosa, Aulacoseira granulata and Nitzschia acicularis that occurred in high biomass in the Warta are common for large rivers (Reynolds and Descy 1996).

A high abundance of Aulacoseira granulata and Nitzschia acicularis was found in the River Warta many years before the present study - in 1953-1960 (Kołaczkowski and Prais 1962). In the current century, besides the previously mentioned taxa, very high biomass of Fragilaria crotonensis has also been recorded. In summer of 2010 and 2016 this species formed water blooms. Its mass occurrence in the Warta confirmed its ability to grow intensively in eutrophic, turbulent waters and its tolerance to light limitation. A water bloom of this species was observed in the Rożnów Reservoir (Bucka and Wilk-Woźniak 2007). Its high biomass was also noted in the summer of 2010 in the section of the River Warta from the Jeziorsko Reservoir to the city of Poznan, in contrast to the station located above the reservoir. This suggested that the main reason for the mass occurrence $F$. crotonensiss in the river was its mass development in the reservoir and good adaptation to the eutrophic river environment (Mądrecka 2015). 
In the case of green algae, many taxa common for rivers were also noted in the River Warta, for instance from the genera: Actinastrum, Coelastrum, Dictyosphaerium, Micractinium, Monoraphidium, Pediastrum, Desmodesmus/Scenedesmus (Reynolds and Descy 1996). For comparison, Hoppówna (1925) in research conducted using net samples almost 100 years ago found a high abundance of the following taxa: Scenedesmus quadricauda, Ankistrodesmus falcatus, A. hantzschii var. fluviatile, Schroederia setigera. Kniat and Kołaczkawski (1963) recorded: Scenedesmus, Pediastrum, Closterium, Chlorella, Zygnema, whereas Kołaczkowski and Preis (1962) found: Scenedesmus quadricauda, Pediastrum boryanum, Dictyopshaerium ehrenbergii, A. hantzschii, $S$. acuminatus, $P$. duplex. The results of the research mentioned above show the similarity of the dominant green alga taxa over the period of approximately one century.

In 2003, 2009 and 2010, a cyanobacterial water bloom was created by Aphanizomenon flos-aquae - a species typical of eutrophic waters. Its occurrence has been described in many Polish dam reservoirs: the Goczałkowice Reservoir (Bucka 1989; Bucka and WilkWoźniak 2007), the Rożnów Reservoir (Bucka 1986; Bucka and Wilk-Woźniak 2007), the Sulejów Reservoir (Palus et al. 2007), the Zemborzyce Reservoir (Sierosławska et al. 2010), and other Polish lakes and reservoirs (Kobos et al. 2013).

In the River Warta the bloom of A. flos-aquae (its biomass $>10 \mathrm{mg} \mathrm{dm}^{-3}$ ) was observed in the second half of summer, when the water temperature was $>22^{\circ} \mathrm{C}$ and $\mathrm{pH}=7.5-9.14$, which corresponded with its optimal value of these parameters given by Bucka and WilkWoźniak (2007) $\left(18-25^{\circ} \mathrm{C}\right.$ and $\left.\mathrm{pH}=7.5-10\right)$. This taxon is able to develop intensively under different environmental stress conditions e.g. nutrient limitation, but requires high insolation and good transparency of water (Burchardt 1998; Bucka and Wilk-Woźniak 2007). In the River Warta it was observed in fascicles flowing near the water surface.

Aphanizomenon flos-aque was not mentioned in Hoppówna's research (1925). The algologist gave the following list of cyanobacteria: Microcystis aeruginosa, Oscillatoria limnetica, O. tenuis, O. sancta, O. chalybea, Anabaena spp.Anabaena spiroides, Gomphosphaeria neageliana, Merismopedia tenuissima, Lyngbya limnetica. It was not recorded by Kołaczkowski and Preis (1962). In the growing season near Saint Roch bridge they found only the following taxa: Oscillatoria spp., O. limosa, O. chlorina, O. princeps, Gleocapsa sp., O. tenera, O. formosa, Merismopedia glauca, Anabeana affinis, M. flos-aquae, Phormidium sp., Spirulina sp., Chroococcaceae. This species was also unrecorded by Kołaczkowski and Preis (1962). They identified the fol- lowing taxa: Oscillatoria spp., Gleocapsa sp., M. glauca, Phormidium sp., M. flos-aquae, Chroococcaceae. These data indicate the very rare occurrence or even absence of this taxon in the River Warta in the past century.

A high biomass of Aphanizomenon flos-aquae was observed in the River Warta in Poznan in the end of July 2005 (Szeląg-Wasielewska et al. 2009). A water bloom of this species was noted in the Warta-Gopło channel in late summer 2005 (Napiórkowska-Krzebietke 2014). It was also recorded in the section of the Warta from the Jeziorsko Reservoir to the city of Poznań in the late summer in 2009 and 2010 (Mądrecka 2015). This was a result of its mass development in the reservoir and it could indicate the very distinct influence of the Jeziorsko on the taxonomical structure and biomass of phytoplankton in the river below the dam. The impact of the Jeziorsko Reservoir on phytoplankton of the River Warta was studied at the end of the $20^{\text {th }}$ century. It was expressed as an increase of taxonomical diversity and abundance of phytoplankton in the river and as changes in the phytoplankton biomass dynamic. The first water bloom of $A$. flos-aque in the Jeziorsko Reservoir was observed in 1994. Its amount was approximately $124 \times 10^{3}$ ind. $\mathrm{cm}^{-3}$ (approx. $99 \%$ of the total phytoplankton abundance) (Galicka and Lesiak 1996a, 1996b; Galicka and Kruk 1999).

In 2016 Woronichinia naegeliana developed intensively in the river and was the major dominant species. This taxon is known to be specific for a wide range of water trophy, but its mass occurrence has been recorded in meso- and eutrophic waters - like those of the Warta. It is found in blooms with other cyanobacteria e.g. A. flos-aquae and Microcystis aeruginosa. Its monoculture is not frequently observed (Wilk-Woźniak et al. 2003). This cyanobacteria is not a very common component of the phytoplankton of Polish lakes and dam reservoirs. It has been observed in 41 out of 238 examined water bodies in Poland e.g. in lakes: Jarosławieckie, Bnińskie, Karczemne (Kobos et al. 2013). It is regularly noted in the Dobczyce Reservoir (Bucka and Wilk-Woźniak 2007). It was also observed in the Siemianówka Reservoir (Grabowska and Pawlik-Skowrońska 2008). In the River Warta it was found about one hundred years ago by Hoppówna (1925).

\section{Conclusion}

The results presented in this work conducted in 2003, 2009, 2010 and 2016 and data obtained from published and unpublished research of the phytoplankton of the River Warta indicate significant changes in its taxonomical structure and biomass during the last one hundred years and show the high likelihood of further modification in the future. Although some difficulties 
were encountered in comparing the results of studies undertaken over a long period, it is possible to draw some general conclusions.

Phytoplankton in the past century was characterized by high taxonomical diversity of diatoms and green algae and its domination in phytoplankton abundance. On the other hand, in the present century, besides these two groups, the mass occurrence of cyanobacteria has been observed. Some of the bloom-forming taxa recorded in the River Warta are specific to rivers. They are colonial green algae: Coelastrum microporum, Micractinium pusillum and unicellular centric diatoms: Stephanodiscus, Cyclostephanos, Cyclotella, Thalassiosira, Actinocyclus and the colonial diatom - Aulacoseira granulata. Additionally, some species more characteristic of dam reservoirs and lakes occurred in high biomass and created water blooms: Fragilaria crotonensis, Aphanizomenon flos-aquae and Woronichinia naegeliana. This phenomenon suggests the influence of the Jeziorsko Reservoir (located approx. $239 \mathrm{~km}$ of river flow above the city of Poznań) on phytoplankton of the River Warta in Poznań, although it obviously does not exclude the impact of tributaries and oxbow lakes located in the catchment area and connected to the river.

It is highly recommended to continue the monitoring research of phytoplankton in Poznan and widen the range of studies within the catchment area of the River Warta to obtain more complex data concerning the origin of bloom-forming species and information about the environmental conditions that they prefer. This is the one of the aims of future research.

\section{Acknowledgments}

The research were partially financed under the inter-university projects: "Studies of bacterioplankton by microscopic and culture methods in the seasonal aspect of water quality and their flow. Validation of methods for the River Warta" (2009) and "The influence of the city of Poznan on the water quality of the River Warta" (2010).

\section{References}

Allan J.D., Castillo M.M., 2009, Stream ecology. Structure and functioning of running waters, Springer, Dordrecht, $436 \mathrm{pp}$.

Al-Tebrineh, J., Merrick, C., Ryan, D., Humpage, A., Bowling, L., Neilan, B.A, 2012, Community composition, toxigenicity, and environmental conditions during a cyanobacterial bloom occurring along 1,100 kilometers of the Murray River, Appl. Environ. Microbiol. 78(1): 263-272.

Amblard C., Carrias J.F., Bourdier G., Maurin N., 1995, The microbial loop in a humic lake: seasonal and vertical vari- ations in the structure of different communities, Hydrobiologia 300/301: 71-84.

Bucka H., 1987, Ecological aspects of the masws appearance of planktonic algae in dam reservoir of southern Poland, Acta Hydrobiol. 29(2): 149-191.

Bucka H., 1989, Ecology of selected planktonic algae causing water blooms, Acta Hydrobiol. 31(3/4): 207-258.

Bucka H., Wilk-Woźniak E., 2007, Glony pro- i eukariotyczne zbiorowisk fitoplanktonu w zbiornikach wodnych Polski Południowej (Pro- and eukaryotic algae of the phytoplankton communities from water bodies in southern Poland), IOP PAN, Kraków, 352 pp (in Polish).

Burchardt L., 1998, The response of Aphanizomenon flosaquae (L.) Ralfs to changes of environmental conditions, Oceanol. Studies 27(1): 9-14.

Carmichael W., 2008, A world overview - One-hundredtwenty-seven years of research on toxic cyanobacteria Where do we go from here?, Adv. Exp. Med. Biol. 619: 104-125.

Dodds W.K., Jones J.R., Welch E.B, 1998, Suggested classification of stream trophic state: distributions of temperate stream types by chlorophyll, total nitrogen, and phosphorus, Water Res. 32(5): 1455-1462.

Galicka W., Kruk A., 1999, Structure of phytoplankton of the Jeziorsko Reservoir (central Poland) in the springautumn period of 1996, Acta Hydrob. 41(1): 17-35.

Galicka W., Lesiak T., 1996a, Composition of phytoplankton in the middle course section of the Warta River, including the Jeziorsko Reservoir (central Poland), Acta Hydrobiol. 38(1/2): 25-33.

Galicka W., Lesiak T., 1996b, Wpływ zbiornika Jeziorsko na fitoplankton środkowego odcinka rzeki Warty (Impact of the Jeziorsko Dam Reservoir on phytoplankton in the Middle Warta River course), Acta Univ. Lodz. Folia Bot. 11: 161-173 (in Polish, English summary).

Gągała I., Izydorczyk K., Jurczak T., Pawełczyk J., Dziadek J., Wojtal-Frankiewicz A., Jóźwik A., Jaskulska A., Mankiewicz-Boczek J., 2014, Role of environmental factors and toxic genotypes in the regulation of microcystinsproducing cyanobacterial blooms, Microb. Ecol. 67(2): 465-479.

Grabowska M., 2012, The role of a eutrophic lowland reservoir in shaping the composition of river phytoplankton, Ecohydrol. Hydrobiol. 12(3): 231-243.

Grabowska M., Glińska-Lewczuk K., Obolewski K., Burandt P., Kobus S., Dunalska J., Kujawa R., Goździejewska A., Skrzypczak A., 2014, Effects of hydrological and physicochemical factors on phytoplankton communities in floodplain lakes, Pol. J. Environ. Stud. 23(3): 713-725.

Grabowska M., Mazur-Marzec H., 2011, The effect of cyanobacterial blooms in the Siemianówka Dam Reservoir on the phytoplankton structure in the Narew River, Oceanol. Hydrobiol. Stud. 40(1): 19-26.

Grabowska M., Pawlik-Skowrońska B., 2008, Replacement of Chroococcales and Nostocales by Oscillatoriales caused 
a significant increase in microcystin concentrations in a dam reservoir, Oceanol. Hydrobiol. Stud. 37(4): 23-33.

[GUS] Główny Urząd Statystyczny (Central Statistical Office), 2016, Ochrona środowiska 2016 (Environment 2016), Wydaw. GUS, Warszawa, 560 pp (in Polish and English). Retrieved from http://stat.gov.pl/obszarytematyczne/srodowisko-energia/srodowisko/ochronasrodowiska-2016,1,17.html [accessed 21 June 2017].

Ha K., Kim H.-W., Joo G.-J., 1998, The phytoplankton succession in the lower part of hypertrophic Nakdong River (Mulgum), South Korea, Hydrobiologia (369/370): 217227.

Hašler P., Hindák F., Hindákowá A., 2007, Phytoplankton of the Morava and Dyje Rivers in spring and summer 2006, Fottea 7(1): 49-68.

Hawley G.R.W., Whitton B.A., 1991a, Survey of algal picoplankton from lakes in five continents, Verh. Int. Ver. Limnol. 24: 1220-1223.

Hawley G.R.W., Whitton B.A, 1991b, Seasonal changes in chlorophyll containing picoplankton population of ten lakes in northern England, Int. Revue Ges. Hydrobiol. 76(4): 545-554.

Hermanowicz W., Dojlido J.R., Dożański W., Koziorowski B., Zerbe J., 1999, Fizyczno-chemiczne badanie wody i ścieków (Physical-chemical examination of water and wastewater), Wydaw. Arkady Warszawa, 556 pp (in Polish).

Hoppówna I., 1925, Plankton rzeki Warty pod Poznaniem (Plankton of the River Warta near Poznań), Pr. Kom. Mat. Przyr. PTPN 3: 1-41 (in Polish).

Istvánovics V., Honti M., Vörös L., Kozma Z., 2010, Phytoplankton dynamics in relation to connectivity, flow dynamics and resource availability - the case of a large, lowland river, the Hungarian Tisza, Hydrobiologia 637: 121-141.

Kasza H., 2009, Zbiorniki zaporowe. Znaczenie - eutrofizacja - ochrona (Dam Reservoirs. Importance - eutrophication - protection.), Wydaw. ATH, Bielsko-Biała, 366 pp (in Polish).

Kentzer A., Dembowska E., Giziński A., Napiórkowski P., 2010, Influence of the Włocławek Reservoir on hydrochemistry and plankton of large lowland river (the Lower Vistula River, Poland), Ecol. Eng. 36(12): 1747-1753.

Kniat J., Kołaczkowski S., 1963, Stan sanitarny rzeki Warty na terenie miasta Poznania (The sanitary condition of the River Warta in the city of Poznań), Pr. Kom. Nauk Podst. Stosow. PTPN 1(4): 1-54 (in Polish, English summary).

Kobos J., Błaszczyk A., Hohlfeld N., Toruńska-Sitarz A., Krakowiak A., Hebel A., Sutryk K., Grabowska M., Toporowska M., Kokociński M., Messyasz B., Rybak A., Napiórkowska-Krzebietke A., Nawrocka L., Pełechata A., Budzyńska A., Zagajewski P., Mazur-Marzec H., 2013, Cyanobacteria and cyanotoxins in Polish freshwater bodies, Oceanol. Hydrobiol. Stud. 42(4): 358-378.

Kołaczkowski S., Preis B., 1962, Zmienność składu fizykochemicznego, biologicznego i bakteriologicznego wody rzeki Warty w Poznaniu (Variability of the physicochemical, biological and bacteriological composition of the waters of the River Warta in Poznań) [manuscript], Instytut Gospodarki Komunalnej, Poznań, 59 pp (in Polish).

Mankiewicz-Boczek J., Palus J., Gągała I., Izydorczyk K., Jurczak T., Dziubałtowska E., Stępnik M., Arkusz J., Komorowska M., Skowron A., Zalewski M., 2011, Effects of microcystins-containing cyanobacteria from a temperate ecosystem on human lymphocytes culture and their potential for adverse human health effects, Harmful Algae 10(4): 356-365.

Mądrecka B., 2015, Dynamika zmian fitoplanktonu w środkowym biegu rzeki Warty i jej wpływ na koncepcje uzdatniania wody (Dynamics of phytoplankton changes in the middle reaches of the river Warta and its impact on water treatment concepts) [Dissertation], Politechnika Poznańska, Poznań, 250 pp (in Polish, English summary).

Merel S., Walker D., Chicana R., Snyder S., Baurès E., Thomas O., 2013, State of knowledge and concerns on cyanobacterial blooms and cyanotoxins, Environ. Int. 59: 303-327.

Mihaljević M., Špoljarić D., Stević F., Cvijanović V., Hackenberger Kutuzović B., 2010, The influence of extreme floods from the River Danube in 2006 on phytoplankton communities in a floodplain lake: Shift to a clear state, Limnologica 40: 260-268.

Mohamed Z.A., Deyab M.A., Abou-Dobara M.I., El-Sayed A.K., El-Raghi W.M., 2015, Occurrence of cyanobacteria and microcystin toxins in raw and treated waters of the Nile River, Egypt: implication for water treatment and human health, Environ. Sci. Pollut. Res. 22: 11716-11727.

Napiórkowska-Krzebietke A., 2014, Phytoplankton of artificial ecosystems - an attempt to assess water quality, Arch. Pol. Fish. 22(1): 81-96.

O’Neil J.M., Davis T.W., Burford M.A., Gobler C.J., 2012, The rise of harmful cyanobacteria blooms: The potential roles of eutrophication and climate change, Harmful Algae 14: 313-334.

Palus J., Dziubałtowska E., Stańczyk M., Lewińska D., Mankiewicz-Boczek J., Izydorczyk K., Bonisławska A., Jurczak T., Zalewski M., Wąsowicz W., 2007, Biomonitoring of cyanobacterial blooms in polish water reservoir and cytotoxicity and genotoxicity of selected cyanobacterial extracts, Inter. Journ. Occup. Med. Envir. Health. 20(1): 48-65.

Pavoni M., 1963, Die Bedeutung des Nanoplanktons im Vergleich zum Netzplankton (The importance of nanoplankton in comparison to net plankton), Schweiz. Z. Hydrol. 25: 219-341 (in German, English summary).

Piontek M., Czyżewska W., Mankiewicz-Boczek J., 2017, The occurrence of cyanobacteria blooms in the Obrzyca River catchment area (Poland), a source of drinking water, Pol. J. Environ. Stud. 26(3): 1191-1201.

Porter K.G., Feig Y.S., 1980, The use of DAPI for identyfying and counting aquatic microflora, Limnol. Oceanogr. 25: 943-948. 
Prygiel J., Leitao M., 1994, Cyanophycean blooms in the reservoir of Val Joly (northern France) and their development in downstream rivers, Hydrobiologia 289: 85-96.

Pułyk M. (ed.), 2010, Stan wód Warty na terenie województwa wielkopolskiego w latach 1999-2009 (Water quality of the River Warta within the Greater Poland Voivodeship in 1999-2009), Wydaw. WIOŚ w Poznaniu, Poznań, 73 pp (in Polish). Retrieved from http://docplayer.pl/37546Inspekcja-ochrony-srodowiska-stan-wod-warty.html [accessed 21 June 2017].

[RZGW] Regionalny Zarząd Gospodarki Wodnej w Poznaniu (Regional Water Management Authority in Poznań), 2007, Charakterystyka regionu wodnego Waty i identyfikacja istotnych problemów gospodarki wodnej (Characteristics of the Warta water region and identification of significant problems of water management), Wydaw. RZGW w Poznaniu, Poznań 67 pp (in Polish). Retrieved from http://poznan.rzgw.gov.pl/images/stories/o_rzgw/ udzial-spoleczenstwa/Charakterystyka-regionu-wodnego-Warty.pdf [accessed 21 June 2017].

Reynolds C.S., 2000, Hydroecology of river plankton: the role of variability in channel flow, Hydrol. Process. 14(16-17): 3119-3132.

Reynolds C.S., Descy J.-P., 1996, The production, biomass and structure of phytoplankton in large rivers, Large Rivers 10(1-4): 161-187.

Severn S.R.T., Munawar M., Mayfield C.I., 1989, Measurements of sediment toxicity of autotrophic and heterotrophic picoplankton by epifluorescence microscopy, Hydrobiologia 176/177: 525-530.

Sierosławska A., Rymuszka A., Kalinowska R., Skowroński T., Bownik B., Pawlik-Skowrońska B., 2010, Toxicity of cyanobacterial bloom in the eutrophic dam reservoir (southeast Poland), Environ. Toxicol. Chem. 29(3): 556560 .
Sługocki Ł., Goździk I., Pilecka-Rapacz M., Czerniawski R., Domagała J., 2014, The effect of environmental factors on the structure of phytoplankton in the lower Odra River, Pol. J. Natur. Sc. 29(2): 137-152.

Stanković I., Vlahović T., Udowič M.G., Várbíró G., Borics G., 2012, Phytoplankton functional and morpho-functional approach in large floodplain rivers, Hydrobiologia 698: 217-231.

Szeląg-Wasielewska E., 2004, Dynamics of autotrophic picoplankton communities in the epilimnion of a eutrophic lake (Strzeszyńskie Lake, Poland), Ann. Limnol. - Int. J. Lim. 40(2): 113-120.

Szeląg-Wasielewska E., Stachnik W., Gawrońska R., 2005, Variability of picophytoplankton communities during cold-water period in small lowland river, Rocz. AR Pozn. 357, Bot.-Stec. 8: 151-159.

Szeląg-Wasielewska E., Zagajewski P., Stachnik W., 2009, Cyanobacterial communities of the lowland Warta River (Poland), Oceanol. Hydrobiol. Stud. 38(Suppl. 2): 1-7.

Weisse T., 1991, The microbial food web and its sensitivity to eutrophication and contaminant enrichment: a cross-system overview, Int. Rev. Ges. Hydrobiol. 76(3): 327-337.

Weisse T., Mindl B., 2002, Picocyanobacteria - sensitive bioindicators of contaminant stress in an alpine lake (Traunsee, Austria), Water Air Soil Pollut. 2: 191-210.

Wetzel R.G. and Likens G.E., 1991, Limnological analyses, Springer, New York, 391 pp.

Wilk-Woźniak E., Bucka H., Mrozińska T., 2003, Contribution to a broadening of taxonomical and ecological knowledge on Woronichinia naegeliana (Unger) Elenkin, Algol. Stud. 109: 609-615.

Zagajewski P., Gołdyn R., Fabiś M., 2007, Water blooms and their toxicity in the public swimming areas in the Poznan district, Oceanol. Hydrobiol. Stud. 36(Suppl. 1): 181-187. 